\title{
How to Improve the Quality of Student Cadres in the Management by Grades Mode
}

\author{
Ying Liu, Xiuzhong Hu, Qianfeng Wang \\ Chongqing three gorges university \\ College of Economics and Management \\ Chongqing, China \\ jsliuying@163.com
}

\author{
Xiaohong Yang * \\ Southwest University \\ College of Horticulture and Landscape Architecture \\ Chongqing, China \\ yangxh2@swu.edu.cn
}

\begin{abstract}
With the increasing expansion of higher education scale in recent years, the construction and management by grades is a hot topic. Under the new times background, the situation puts forward higher requirement for the students management staff. This article was written from the management by grades point of view, analyzed the basic condition and advantage. This thesis focused on how to train and improve the quality of student cadre.
\end{abstract}

Keywords-colleges and universities; the management by grades; management model; the quality of student cadres

\section{INTRODUCTION}

With the national economic structure deepen the reform and colleges and universities continue to expand enrollment, a great change in university student's thinking has come about.The collision between the old and new ideas and the conflict between power and rights greatly challenges the work of college students management.The conduct of the management of college students face many obstacles, and to guide and strengthen the management of university students is an urgent task.To increase "level" and "structure" has become an inevitable choice to improve the quality of Education Management. The management by grades is a new mode.The management by grades is extremely important for college management :In order to alleviate the burden of teachers and improve student learning efficiency provides reliable guarantee,for another promote the interests of student's studying, and improve teaching quality.The building of an excellent student cadre corps is an important basic project in collegiate student work.Therefore, it is necessary to strengthen the construction of the team of student cadres by helping them to be well-motivated and develop a "learning-first" attitude and making greater efforts to improve their overall quality and practical ability.

\section{FUNDAMENTAL PATTERN OF MANAGEMENT BY GRADES}

The management by grades responsibility and authority for grade redefine.It can strengthens management dynamics .

\section{A. Positioning Gradein School Management}

In the traditional university management the management by grades is in fourth, which is not conducive to the implementation of school uniform resolution.Grade is an important management object and the main part of the chool managements,so it influence the whole construction and development of the school.The management by grades could better enforce school resolution and feed back the basic situation of the students better.

\section{B. The Management by Grades Members}

According to the characteristics of grade learning, social activities and other specific conditions, colleges and universities could choose in professional managers who Familiar with the students learning task, social activities and mental state etc.

\section{The Management by Grades Duties}

The object of the management by grades is students,so its duty is to Enable the students to achieve better development in various social activities,learning,life and so on.

\section{The management by Grades Assessment}

We can visually examine each branch, each grade of students management work of concrete and their real situation through the management by grades. Through the comparison of various grade management, appraisal management grade score.Through the summary of each grade management, the overall management of school situation can be seen.

\section{THE ADVANTAGES OF MANAGEMENT BY GRADES ASSESSMENT}

The practice and application in the management by grades is an ambitious response to improve the management level.This mode has the following advantages:

\section{A. Simplify the Management}

To simplify the management level,the management is more directly and effective.Each grade of university students have different learning tasks, social activities and mental aspects.Psychology: freshman may be due to the strange new environment, cause a series of psychological problems of sense of loss; senior student may be due to the difficult problem of employment, bring pressure and the negative psychological problems.Learning:the main study is public basic knowledge,so 
freshman will feel more relaxed;but junior student learn the professional knowledge,the pressure to study is great.Social activities:freshman and sophomore do some easy internal school activities,junior student and senior student take part in some social activities.It includes four parts: first, as a freshman, adaptation and self-analysis; second, as a sophomore, initial analysis of occupation and orientation; third, as a junior, planning career life and fully preparing for it; fourth, as a senior, correctly choosing the career and realizing the goal.In a word,the management by grades can solve the problem professional and effectively[1].

\section{B. Improve the Service Evel of Education Administration}

A comprehensive understanding of students can promote education and management development,improve the service level of Education Administration.Grade and student near,This helps a better understanding of students. The management by grades can improve the student's education management level.

\section{Shorten the Distance with Students}

The school to participate directly in the line management, shorten the distance with students, long-term development is conducive to the management of the school.

\section{Improve the Overall Management Level of the School}

Different grades display their energy,To form the positive competition with each other, learn from each other, learn from each other, help to improve the overall management level of the school.

\section{E. The manager Can Quickly Growth}

After the management by grades,each link of management, such as planning, implementation, examination, summary and feedback, grade have to completed personally, The manager can quickly growth and accumulated practical experience in practice,Training talents of sustainable development for schools.University grade management is a complex and longterm task,Grade management is the first line of management work, Through the work planning,implementation,summary and so on a series of concrete practice,Can cultivate outstanding management personnel having a really hard work or the school.

\section{HOW TO IMPROVE THE QUALITY OF STUDENT CADRE}

University student cadres are bridges and links between all kinds of student organizations and students, are concrete participants and executors of university education and management systems.Hence,we should enhance college student cadre's basic ability by cultivating their natural personality charm, ability for organization and harmonization, and ability for interpersonal communication.University student cadres are very active and aggressive. The overall tread is healthy and upward, with positive world outlook, life outlook, mainstream orientation of values, practical initiative, and deep sympathy and sense of belonging to our country society's mainstream ideology.

\section{A. Establish strict Selection Mechanism}

University must enhance their sense of competition in a fast-paced and high-pressured society,and university student cadres is no exception. The academic motivation of the students at university is utilitarian,they want increased knowledge get exercise and earn rewards, .Join the Party ,for example, they are only in order to increase job opportunities.Part of the university student cadres regarded lei's spirit as being outdated .The lack of gratitude is a serious problem fling contemporary college students.Most of university student cadres are the only child and petted in every way.They always center yourself and never think about others. They take the help of others for granted,such as their parents for their fostering,teachers` enlightenment and instruction, and the help of friends. Set up a cultivation, appraisal, mechanism which chooses student cadre with rational science through the reform, arouse their enthusiasm. The election should be conducted fairly, openly and honestly[2].

\section{B. Enhance the Education Theoretical Knowledge}

More trainings are lack the knowledge of pedagogy psychology and management studies, affecting work efficiency.

So,they should be held to enhance university student cadres cadre skills and help them better serve the students.Ways to improve: have meetings with excellent student cadres to exchange experience, lectures by famed teachers, communication and feedback, inspiring lectures.Through the training,students can through the oretical study and improve political quality.

\section{Organize University Student Cadres 'Social Practice}

To organize university student cadres' social practice is an important means of carrying out quality education and improving students' knowledge and skills as well as their creativity and practical abilities, and promoting school reform.Information literacy of the college student accomplishment needs to be taken exercise and checked in social practice.Social practice can help university student cadres able to self-supporting and adapt to the social life.

\section{Competence of Interpersonal Communication}

With the rapid development of network technique, internet communication is becoming more common and important.Eighty percent college students have computer in chongqing three gorges university. Some contemporary graduated student's wallow in the network extricate oneself with difficulty.Those who indulge in the internet often feel isolated and being cut off from the outside world, gradually they tend to become introverted, withdrawn and unsociable.After they began to work, university student cadres have to Harmonize the relationship between the members or departments in the company.University student cadres should be good at coordination and communication;These interpersonal skills training is particularly important.In "The second class " , students learn to cooperate and compromise, and develop interpersonal skills needed for future success. 


\section{E. Enhance Team Working Ability}

University student cadres are all single children.Their family is the focal point of their lives. Sometimes they only think about themselves!What is more, in the child's self-centred world, they are all too ready to shoulder responsibility.University student cadres are the hope of the family.So some parents are spoiling their children and that will only make them over dependent and incapable of making their own decisions and choices.Because they have no brothers or sister,they seem to care little about others, shut down communication and indulge in their own worlds. A recent study, by researchers at the university of michigan, found that college students today have significantly less empathy-the ability to understand and share the feelings of another-than students of generations past did.They have no good communication skills and team cooperation spirit.Every year many universities will arrange some student activity according to the particular case,such as:various commemoration,learn-from-Lei Feng,all kinds of sports ,competitions.Rich and colorful campus cultural life can create friendly atmosphere, making learning enjoyable Good organization ability and teamwork spirit and strong collective sense of honor.Through "the second class " ,university graduates could be good organization ability and teamwork spirit and strong collective sense of honor[3].

\section{F. Enforcing Psychological Counseling}

University student cadres are so self-important that he can't take a joke.They are looking for affirmation, direction, and hope,but at the same time, they're unwilling to accept criticism and admit mistakes Blame may lead to a strong reverse psychology.Most contemporary graduated student's come from good homes,and get a lot of attention.They don't have good mental quality and strong communication skills.It will have a huge psychological impact when they are in face of a series of blows.It is an imperious task for education teaching in colleges and universities to probe into the causes of learning frustration of the education participants and adopt the proper educational handling to improve their anti-setback ability.Maintaining a good attitude,shaking off professional sluggishness and enhancing the sense of self-value is very important.

\section{G. Develop Expertise and Capabilities}

University student cadres are not only need social skills,but also with strong technical knowledge. Usually doesn't study hard, some university student cadres are poor at expertise and capabilities.Universities can Invite relevant experts and scholars to do lectures according to the particular case.Development of scientific research in the university is a vital approach to enhance comprehensive faculties of university student and cultivate new talented person.Universities also can organize the professional competition to develop the students ,expertise and capabilities.Activities are also beneficial to the students intellectual development, emotional development, to enhance student participation in awareness, sense of competition, to develop students the spirit of cooperation spirit and sense of innovation.University student cadres have not only professional theory knowledge and professional skill but also higher emotional quotient level.

\section{H. Strengthen Supervision and Science Assess}

Colleges and universities should strengthen the system construction,establish a scientific and effective mechanism for monitoring and evaluation.Not only on the student cadres work, learning, performance evaluation, but also to the general student assessment opinion of student cadres; We stand for the principle, "to each according to his work", and we favour public citations and material rewards for those students that have made outstanding contributions.For the unqualified student cadres, we should give good criticisms and comments and suggestions.Incompetent cadres should be promptly removed.As a student cadre, always conscious of its responsibilities and obligations in no way relax its own requirements, always be pioneers, not afraid of hard work.

\section{Focus on Training}

The school should fully respect and care of student cadre, to create a harmonious relationship between teachers and students.In work,school should put strict demands on them,given the full trust and correct guidance; In daily life,often should communicate with them, understand their needs,solve their practical difficulties,show concern for their growth,and make the student cadres have the sense of belonging.In addition,we should pay attention to teach students in accordance with their aptitude,tap the potential,and take different incentives for different cadres. So they can bold work, give full play to strong points, in the work gradually improve the quality of theirslves.

\section{REFERENCES}

[1] Feng Shu-lin, The practice and reflection about the management by grades in vocational college,Shijiazhuang Vocational College of low and Commerce Teaching and Research.,vol.06,pp.5-7,sep 2010.

[2] WANG Ming,YU Hai-li,The Basic Approaches for Instructors to Educate and Manage College Students Born After 1990,Journal of North China Institute of Water Conservancy and Hydroelectric Power(Social Sciences Edition),vol.03, pp.143-145,June 2012.

[3] SHI Xiang-jun, ZHANG Qiong,,"After 90"Characteristics of Thoughts and Behaviors and the Ideological and Political Education Method, Journal of Chongqing University of Technology( Social Science),vol.27,pp.72-75, january 2013. 